\title{
Article: Pengalaman Emosional Lelaki Seks Lelaki dalam Menghadapi Upaya yang Dilakukan Setelah Terdiagnosa HIV di Puskesmas Simpang Kawat Kota Jambi Tahun 2019
}

\author{
Tedy Asharyadi ${ }^{1}$, Budhi Mulyadi $^{2}$, Mahathir ${ }^{3}$ \\ Program Studi Magister Keperawatan, Fakultas Keperawatan, Universitas Andalas \\ Jl. Limau Manis, Kecamatan Pauh, Sumatera Barat 25163, Indonesia \\ Email: teddyasharyadi91@gmail.com
}

\begin{abstract}
Emotional feeling of men who have sex with men (MSM). This study showed the experience on facing the emotional feeling of men who have sex with man (MSM) after diagnosed having HIV with their partners. This study using qualitative approach with descriptive phenomenology design, the number of participant was 20 people, and getting by in depth interview. Secluding from society often done by people who diagnosed having HIV, asking the information about HIV and how to cure it and getting closer to God for healing. Caring the Men who have sex with man with HIV by more emphaty feeling.
\end{abstract}

Keywords: Emotional feeling of men who have sex with men (MSM) facing the problem after diagnosed with HIV.

\section{PENDAHULUAN}

HIV/AIDS telah berkembang menjadi salah satu masalah kesehatan dan sosial yang besar dan penting di seluruh Indonesia. Sejak tahun 1999, kasus HIV positif dan AIDS yang ditemukan memperlihatkan kecenderungan yang terus meningkat. Jumlah kasus yang dilaporkan relatif rendah, tetapi dari berbagai studi dilaporkan diperkirakan bahwa jumlah kasus yang sesungguhnya jauh lebih besar. Menurut World Health Organization (WHO, 2017), merupakan masalah dan tantangan serius terhadap kesehatan masyarakat di dunia. Jumlah Orang Dengan HIV/AIDS (ODHA) di seluruh dunia diperkirakan sudah mencapai 33,2 juta $(30,6-36,1$ juta) .

Setiap hari, lebih 6800 orang terinfeksi HIV dan lebih dari 5700 meninggal karena AIDS, yang disebabkan terutama kurangnya akses terhadap pelayanan pengobatan dan pencegahan HIV. Fast Track Strategy UNAIDS tahun 2014 menyatakan tujuan yang harus dicapai negara-negara dalam pengendalian AIDS di dunia yaitu $90 \%$ status HIV diketahui, $90 \%$ mendapatkan pelayanan perawatan dan pengobatan, penurunan kasus infeksi baru hingga 500.000 dan nol diskriminasi di tahun 2020 (UNAIDS, 2017) .

Human Immunodefiency Virus dan Acquired Immuno Deficiency (AIDS) disebabkan oleh infeksi virus HIV yang menyerang sistem kekebalan tubuh yang ditularkan melalui cairan tubuh penderita yang terjadi melalui proses hubungan seksual, transfusi darah yang tidak aman, penggunaan jarum suntik secara bergantian yang terkontaminasi HIV dan penularan dari ibu yang terinfeksi HIV/AIDS ke anak dalam kandungan. Salah satu kelompok yang berisiko tertular HIV adalah kelompok LGBT. Fenomena lesbian, gay, biseksual dan transgender, atau yang biasa disingkat LGBT merupakan salah satu fenomena yang saat ini mengalami peningkatan kasus di dunia (Shubber et al, 2014).

(Remis et al, 2014). Menyatakan bahwa kelompok LSL merupakan kelompok populasi yang berisiko tertular HIV karena perilaku seksual berisiko seperti melakukan anal seks tanpa kondom dan pelicin serta berganti-ganti pasangan seksual. Risiko penularan HIV yang dimiliki LSL karena hubungan seks tidak aman. (Putri, 2017). Prilaku seks tidak aman yaitu melalui seks anal maupun oral (Fauziyah et al, 2018). Dari penjelasan di atas dapat diketahui bahwa banyaknya peningkatan LSL berhubungan dengan meningkatnya pula jumlah ODHA dari kalangan LSL. Hal tersebut karena LSL dapat menularkan HIV/AIDS. HIV merupakan penyakit yang menular dan mematikan, sehingga menjadi perhatian serius bagi seluruh dunia.

(Aidala et al, 2018) pengalaman pada lelaki seks lelaki yang terkena HIV memiliki pengalaman yang berbeda mulai dari perilaku dan penerimaan diri terhadap penyakit yang dialamiya. (Harrison \& Shortall, 2016) menyatakan LSL yang terkena HIV menunjukakan tanda gejala distress psikologi dan kesehatan Jiwa pada kelompok LSI tersebut. Lelaki Seks Lelaki (LSL) mengalami depresi dan harga diri yang rendah kerena mengetahui serostatus postif HIV Baird, Sarah et al, 2016).

Pengetahuan dan informasi secara terus menerus dan berkesinambungan yang memadai tentang kesehatan dan mempunyai kesadaran yang mendukung perubahan perilaku, seperti setuju terhadap tindakan pencegahan dengan menggunakan kondom secara konsisten pada setiap kali hubungan seks maupun tindakan lainnya (Dermatoto, 2015).

\section{METODE PENELITIAN}

Penelitian ini merupakan penelitian kualitatif menggunakan desain penelitian "Fenimenologi deskritif". Populasi dalam penelitian ini adalah lelaki seks lelaki dengan HIV di Puskesmas simpang kawat kota Jambi berjumlah 20 orang. Teknik pengambilan sampel yang digunakan dalam penelitian ini adalah teknik Colaizzi dengan metode Purposive sampling.

\section{HASIL DAN PEMBAHASAN}

Adapun hasil dari penelitian ini dapat dilihat pada tabel berikut ini :

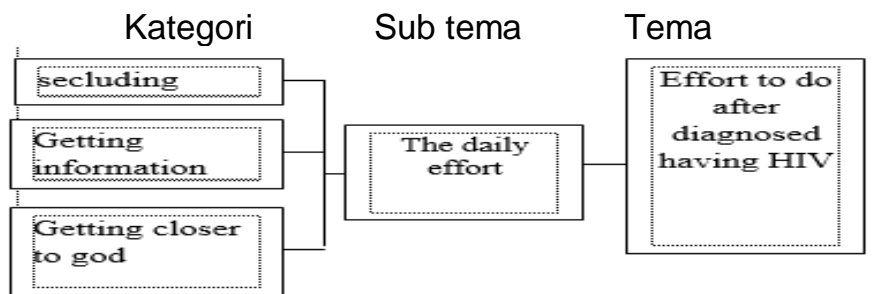

Skema Tematik 1. Respon Emosional 
Berdasarkan tabel skema diketahui bahwa partisipan mengatakan setelah terdiagnosa HIV lebih banyak menyendiri karena tidak ingin bertemu dengan siapa-siapa, mencari informasi tentang penyakitnya serta mendekatkan diri kepada tuhan yang maha esa sebagai ungkapan beberapa partisipan sebagai berikut:

\section{"cuma sampai menyendiri dikamar beberapah hari"}

"ya paling menyendiri merenungi apa yg sudah terjadi dak mau diganggu, pokonya mau jauh-jauh dulu la dari orang-orang"

"Nangis, menyendiri dikamar, kadang melamun"

Partisipan mengatakan lebih banyak bertanya kepada orang-orang yang tau sama HIV dan menggali informasi pengobatan, seperti yang diungkapkan partisipan P5, P16 dan P19 berikut ini:

"hmmm banyak searching sama banyak kepo terutama ya sama dari pihak puskesmas ini sama kakak kami banyak tanya"

"terus menggali informasi pengobatan, karena tentunya di Jambi ada teman2 dari Yayasan selalu mempromosikan bahwasanya ada teman2 yg sudah tahunan minum ARV bisa bertahan hidup"

"terus nanya-nanya sama konselor juga"

", kita harus rutin bertanya kepada orang-orang yang tau sama HIV dan ikut LSM"

Partisipan mengatakan lebih mendekatkan diri kepada Tuhan agar merasa tenang, seperti yang diungkapkan partisipan P5 dan P8 berikut ini:

"Aku sekarang ini coba mendekatkan diri ke Tuhan, dengan berdoa terasa lebih tenang"

"mendekatkan diri dengan Allah, agar kedepannya hidup lebih baik lagi"

\section{"pertama kali Tuhan yang memberi kita umur"}

Saat dilakukan wawancara partisipan terlihat menunduk dengan wajah datar dan sesekali tersenyum.

\section{PEMBAHASAN}

Berdasarkan skema diketahui bahwa partisipan mengatakan setelah terdiagnosa HIV lebih banyak menyendiri karena tidak ingin bertemu dengan siapasiapa, mencari informasi tentang penyakitnya serta mendekatkan diri kepada tuhan yang maha esa sebagai ungkapan beberapa partisipan sebagai berikut

Respon emosional partisipan yaitu mengatakan setelah didiagnosa HIV dia lebih banyak menyendiri karena tidak ingin bertemu dengan siapa-siapa, lebih banyak bertanya kepada orang-orang yang tau sama HIV dan menggali informasi pengobatan dan lebih mendekatkan diri kepada Tuhan agar merasa tenang. Untuk merubah perilaku pada seseorang yang telah didiagnosa HIV positif yaitu dengan peningkatan pengetahuan dan kesadaran terhadap HIV positif yaitu dengan melakukan strategi khusus kepada kelompok sasaran primer seperti LSL yang berisiko tinggi. Prinsip perubahan perilaku bahwa jika seseorang tahu dan mempunyai pengetahuan dan informasi secara terus menerus dan berkesinambungan yang memadai tentang kesehatan dan mempunyai kesadaran yang mendukung perubahan perilaku, seperti setuju terhadap tindakan pencegahan dengan menggunakan kondom secara konsisten pada setiap kali hubungan seks maupun tindakan lainnya. (Dermatoto, 2015). Penelitian ini sama dengan penelitian yang dilakukan oleh Aditya tentang perilaku berganti ganti pasangan tanpa adanya pemakaian kondom yang konsisten, yang demikian sangat memungkinkan terjadinya transmisi penyakit menular seksual. Karena pasangan mareka tidak di ketahui riwayat dan status kehidupan seksual sebelumnya. Perilaku seksual yang meluas juga meningkatkan resiko penularan HIV pada LSL dan pasanganyaan sesama jenis (Aditya, 2014).

Perilaku untuk mencapai penerimaan diri terhadap status HIV positif pada gay didukung oleh beberapa hal. Hal pertama yang mendukung penerimaan diri pada gay terhadap status HIV positif adalah melihat orang lain yang memiliki kondisi dan status yang sama dengan diri sendiri masih sehat. Kedua adalah adanya dukungan dari orang-orang terdekat responden seperti, temanteman dari Kelompok Dukungan Sebaya (KDS), konselor, keluarga dan pasangan. Adapun dukungan yang diberikan oleh orang-orang terdekat responden meliputi mendampingi responden ketika responden merasa terpuruk dan down, memberi semangat, selalu mengingatkan untuk hidup sehat dan satu sama lain saling mengingatkan dengan teman yang memiliki kondisi yang sama. Hal ketiga yang mendukung gay untuk mencapai penerimaan diri terhadap status HIV positif adalah adanya kesadaran dari diri sendiri bahwa status HIV positif yang dimiliki saat ini merupakan hasil dari perilaku seksual yang berisiko dan tidak aman.

Adanya hal-hal yang mendukung mencapai penerimaan diri tersebut menghasilkan perilaku mencapai penerimaan diri pada gay terhadap status HIV positif. Adapun perilaku yang ditunjukkan oleh gay adalah memberitahu orang-orang terdekat partisipan, seperti pasangan dan keluarga, melakukan konseling dengan konselor. Tidak hanya melakukan konseling, responden juga melakukan kontak dengan konselor di luar sesi konseling. Selain mencari informasi tentang HIV pada konselor, responden juga mencari informasi di internet, buku, maupun brosur-brosur yang tersedia di layanan ketika melakukan konseling. Setelah mendapatkan informasi yang cukup tentang HIV dari berbagai sumber, hal yang dilakukan selanjutnya adalah mengubah kebiasaan yang dilakukan sebelum mengetahui status HIV positif seperti mengurangi aktifitas kumpul bersama teman dan keluar malam untuk dugem atau minum minuman beralkohol. Hal itu dilakukan karena dapat memengaruhi kesehatan dan terapi. Adanya kesadaran akan perilaku seksual yang berisiko membuat gay yang memiliki status HIV positif 
lebih memikirkan berhubungan seksual dengan banyak orang, merubah kebiasaan perilaku seksual, yang awalnya jarang menggunakan kondom menjadi selalu menggunakan kondom saat berhubungan seksual.

Partisipan mengatakan bahwa dengan bertanya ke layanan/konselor dan LSM Kanti Sehati ataupun ke teman-teman yang sudah menderita HIV, partisipan mendapat mendapatkan informasi banyak mengenai HIV dan ternyata banyak teman-teman yang menderita HIV yang bertahan hingga sekarang, sehingga mereka bersemangat untuk sehat.

Dalam penelitian ini diketahui bahwa ODHA yang memiliki informasi mengenai HIV/AIDS bahkan terhadap resiko perilakunya berpengaruh terhadap penerimaan diri ODHA terhadap status penyakitnya. ODHA yang tertular melalui perilaku beresiko serta memiliki informasi mengenai HIV/AIDS akan lebih mudah dalam menyesuaikan diri serta dapat menerima penyakitnya dengan lebih cepat (Burhan et al, 2014).

Perawat berperan penting dalam memberikan informasi bahwa ODHA perlu memperoleh pengobatan. (Nursalam \& Dian, 2015) mengungkapkan perawat memiliki peran penting dalam mengarahkan ODHA untuk menggunakan koping yang konstruktif dalam beradaptasi dengan penyakitnya. Hasil penelitian diperoleh bahwa ODHA tergugah dengan arahan dari petugas kesehatan untuk melakukan pengobatan ke Puskesmas. Hal tersebut mengungkapkan bahwa dukungan yang diberikan oleh petugas kesehatan sangat mempengaruhi pengambilan keputusan dan tindakan ODHA untuk melakukan pengobatan.

Kegiatan membagi perasaan dan informasi membantu ODHA memperoleh informasi yang benar mengenai penyakit HIV AIDS sehingga mengubah kesalahpahaman ODHA tentang penyakit HIV AIDS. Günthard et al, 2016) mengungkapkan bahwa ODHA perlu mengetahui prognosis penyakit HIV AIDS untuk mengubah kesalahpahaman ODHA tentang cara penularan penyakit HIV AIDS, melindungi pasangan dan orang yang dicintai, mencegah penularan dari ibu ke anak, meningkatkan kesadaran pentingnya pengobatan. Kegiatan membagi perasaan dan informasi juga membantu ODHA memperoleh saran untuk terus berobat dari petugas kesehatan. (Hutasoit \& Widowati, 2017) mengungkapkan perasaan dan informasi membantu ODHA mendapatkan dukungan emosional, akses terhadap pengobatan dan perawatan. Kegiatan membagi perasaan dan informasi juga dapat memberikan kesempatan ODHA untuk mengekspresikan pikiran dan perasaan (Chaudoir \& Fisher, 2010).

Partisipan mengatakan bahwa mereka pasrah dan lebih banyak mendekatkan diri kepada Tuhan agar merasa tenang. Partisipan menganggap bahwa HIV merupakan peringatan dari Tuhan bahwa waktu subjek di dunia sudah tidak banyak. Hal tersebut membuat subjek tergerak untuk bermanfaat bagi orang yang membutuhkan. Empati merupakan kemampuan individu untuk bias membaca dan merasakan bagaimana perasaan dan emosi orang lain. Empati sangat erat kaitannya dengan kemampuan individu untuk membaca kondisi emosional dan psikologis orang lain (Parkins, 2014).
ODHA juga menyadari apa yang menimpanya adalah akibat kesalahan sendiri, dan mereka menganggap hal tersebut ujian dari Allah SWT agar mereka menjadi manusia yang lebih baik. Allah swt juga menjelaskan bahwa bagi orang-orang yang menyadari kesalahannya dan memohon ampunan kepada Allah SWT maka Allah SWT akan mengampuni dosanya (Yansah, 2018).

\section{SIMPULAN}

Upaya yang dilakukan menghadapi emosional setelah didiagnosa HIV adalah lebih banyak menyendiri karena tidak ingin bertemu dengan siapa-siapa, lebih banyak bertanya kepada orang-orang yang tahu sama HIV dan menggali informasi pengobatan serta lebih mendekatkan diri kepada Tuhan agar merasa tenang.

\section{DAFTAR PUSTAKA}

World Health Organization (WHO). (2017). Global AIDS Update 2016. Joint United Nations Programme on HIV/AIDS. South Africa. https://doi.org/ISBN 97892-9253-062-5

UNAIDS. Combination HIV Prevention: Tailoring and Coordinating Biomedical, Behavioural and Structural Strategies to Reduce New HIV Infections (2017).

Shubber, Z., Mishra, S., Vesga, J. F., \& Boily, M. C. (2014). The HIV Modes of Transmission Model: A Systematic Review of Its Findings and Adherence to Guidelines. Journal of the International AIDS Society, $17(5), \quad 1-14$. https://doi.org/10.7448/IAS.17.1.18928

Remis, R. S., Alary, M., Liu, J., Kaul, R., \& Palmer, R. W. H. (2014). HIV Transmission among Men Who Have Sex with Men Due to Condom Failure. PLoS ONE, $9(9)$ $1-7$. https://doi.org/10.1371/journal.pone.0107540

Putri Uli Saktina, B. K. S. (2017). Karakteristik Penderita AIDS dan Infeksi Oportunistik di Rumah Sakit Umum Pusat Sanglah Denpasar. E-Jurnal Medika, 6(3), 1-6.

Fauziyah, F., Shaluhiyah, Z., \& Prabamurti, P. N. (2018). Respon Remaja Lelaki Suka Lelaki (LSL) dengan Status HIV Positif terhadap Pencegahan Penularan HIV kepada Pasangan. Jurnal Promosi Kesehatan Indonesia, 13(1), https://doi.org/10.14710/jpki.13.1.17-31

Aidala, A. A., Lee, G., Howard, J. M., Caban, M., Abramson, D., \& Messeri, P. (2018). HIV-Positive Men Sexually Active with Women: Sexual Behaviors and Sexual Risks. Journal Of Urban Health, 83(4), 637-655. https://doi.org/10.1007/s11524-006-9074-1

Harrison, M. A., \& Shortall, J. C. (2016). Women And Men In Love: Who Really Feels It and Says It First. Journal of Social Psychology, 151(6), 727736 https://doi.org/10.1080/00224545.2010.522626

Baird, Sarah,Erick gong,Mclntosh, C., \& Özler, B. (2016). The heterogeneous effects of HIV testing. Journal of Health Economics, 37(1), 98-112. https://doi.org/10.1016/j.jhealeco.2014.06.003

Dermatoto, A. (2015). Perilaku Laki-Laki Yang 
Berhubungan Seks Dengan Laki-Laki (LSL) Untuk Melakukan Test Hiv. Public Healtth Science Jornal, 3 ,

Dermatoto, A. (2015). Perilaku Laki-Laki Yang Berhubungan Seks Dengan Laki-Laki (LSL) Untuk Melakukan Test Hiv. Public Healtth Science Jornal, 3, 1-4.

Aditya ER. (2014). Perilaku penggunaan kondom Secara Konsisten untuk pencegahan HIV. Published In, 4, 1-20.

Burhan, R. F., Fourianalistyawati, E., \& Zuhroni. (2014). Gambaran kebermaknaan hidup orang dengan hiv/aids (odha) serta tinjauannya menurut Islam. Jurnal Psikogenesis, 2(2), 110-122.

Nursalam, M., Dian, N. (2015). Asuhan Keperawatan Pada Pasien Terinfeksi HIV/ AIDS. Public Healtth Science Jornal, 3, 1-20.

Günthard, H. F., Saag, M. S., Benson, C. A., Rio, C., Eron, J. J., Gallant, J. E., ... Gandhi, R. T. (2016). Antiretroviral Drugs for Treatment and Prevention of HIV Infection in Adults. Published in Final, $316(2)$, $1-47$. https://doi.org/10.1001/jama.2016.8900.Antiretrovi ral

Hutasoit, F. E., \& Widowati, E. (2017). Jurnal of Health Education, 2(1), 66-72

Chaudoir, S. R., \& Fisher, J. D. (2010). The Disclosure Processes Model: Understanding Disclosure Decision Making and Postdisclosure Outcomes Among People Living With a Concealable Stigmatized Identity. Psychological Bulletin, 136(2), https://doi.org/10.1037/a0018193

Parkins, R. (2014). Gender and emotional expressiveness: An analysis of prosodic features in emotion expression. Griffith Working Papers in Pragmatics and Intercultural Communications, 5(1), 1-9.

Yansah, R. (2018). Globalisasi lesbian, Gay, Biseksual, dan Transgender (LGBT): Perspektif HAM dan Agama dalam Lingkup Hukum di Indonesia. Law Reform Program Syudi IImu Hukum Fakultas Hukum Universitas Diponegoro, 14(1), 132-146. 